\title{
International Alliance Strategies: A Case Study of the Indonesian Medical Device Industry
}

\author{
Aluisius Hery Pratono and Rosalia Vita Septina Ratih
}

\begin{abstract}
This study aims to investigate how the multinational corporations form alliance strategies with local businesses under the dynamic institutional environment in the Indonesian context. We used a qualitative approach with a case study of the medical device industry to examine how the institutional environment affects the choice of the strategic alliance. By collecting the qualitative data, including interviews, observations and archival data, the interpretive approach was adopted to understand social worlds from the point of view of participants. We identified five types of alliance strategies: the wholly owned subsidiary with contractual collaboration, the wholly owned subsidiary with the licence agreement, the international trade with the licence agreement, joint venture and outsourcing. There are also two main issues of the institutional environments that determine the choice of alliance strategic: the restriction for foreign companies to carry out direct selling and the new policy that introduces the electronic procurement system. This study provides evidence of the role of the institutional environment on collaboration strategies between the multinational enterprises from the developed countries and the local distributors from Indonesia. The results extend the concept of international business in the Asian context.
\end{abstract}

\section{Introduction}

Indonesia is one of the emerging market economies where the healthcare market will experience a dramatic growth from USD 7 billion in 2014 to USD 32 billion in 2019 (Frost and Sullivan 2016). The Indonesian healthcare market was estimated to be worth $\$ 50$ billion by 2020 , as the total annual value of the healthcare device market reaches US $\$ 900$ million per annum. The national government budgetary expenditure on health amounted to US\$39 per capita in 2014 and had become the second largest

\footnotetext{
A. H. Pratono (ه)

Universitas Surabaya, Surabaya, Indonesia

e-mail: hery_pra@staff.ubaya.ac.id

R. V. S. Ratih

Universitas Gadjah Mada, Yogyakarta, Indonesia
} 
source of financing for healthcare with a population of more than 230 million (World Bank Group 2016).

Such a situation raises opportunities and challenges for the local business organisation, wherein they need to enter partnerships with the global players. Literature has shown that strategic alliance offers opportunities for the multinational enterprises to leverage their local partner's unique resources, to expand their distribution network, to gain competitive advantages and to improve financial returns (Gomes et al. 2016). The emerging economies demonstrate the dramatic institutional transitions, which result in the firm's strategic choices and performance (Peng 2003; Young et al. 2014).

Most multinationals experienced a stumble over the strategic alliance for penetrating markets in emerging countries (Arnold 2000). However, there is little information about the role of the institutional environment on strategic alliance choices and performance in the marketing literature (Gomes et al. 2016). Recent review papers urge the need of more institution-based research on the contradicting relationship between the choices of alliance and consolidation modes and firm performance (Lebedev et al. 2015; Xie et al. 2017). Drawing from the case study of the medical device industry in Indonesia, this study has the intention to address the primary research question on how institutional environment determines the choice of a strategic alliance in B2B.

This article discusses the unique features of the Indonesian institutional environment and the alliance strategies of foreign and local companies in the medical sector in Indonesia by addressing the research question on (1) how pressure of institutional environment determines the multi national enterprises' engagement in Indonesia medical device industry, (2) what are the alliance strategies between multinational companies and local firms in the medical sectors to respond to the policy and (3) why the multinational companies choose the strategy. This study involved various stakeholders in understanding the phenomenon of the international alliance strategies in the observed country, Indonesia. By collecting the qualitative data, including interviews, observations and archival data, the interpretive approach was adopted to understand social worlds from the participants.

\section{Literature Review}

\subsection{Types of Market Penetration in Emerging Countries}

The literature shows four types of multinational enterprise's strategy for penetrating in emerging countries. The company may establish a subsidiary venture, while others prefer to alliance strategy with local companies. Alliance strategy is a voluntary arrangement between business organisations, which involves exchange resources with various motives and goals (Rossignoli 2015). 


\section{Wholly Owned Subsidiaries}

This approach emphasises the role of headquarter in controlling the local entities by providing universal standardised products. In this model, the global companies prefer to take a lead for global integration in operations being uniform. At the organisational aspects, corporations establish their subsidiaries in different countries and delegate operations to them as a strategy of pursuing business on a global scale (Motohashi 2015). The approach is about trust building, which may allow their salespeople to become more confident to deal with asymmetric information, such as misrepresenting products and outright fraud (Pratono 2018).

The internal embeddedness will bring about the willingness of the corporations to share their valuable intangible assets (Contractor et al. 2016). Japan is the best example for multinational companies, which rely on the foreign ownership level as well as the experience level of the parent companies (Gaur and Lu 2007). The Japanese companies typically take the acquisition of local partners after facing several drawbacks, such as no agreement between the multinational company and local partner (Motohashi 2015). Different context may bring different story from the Japan companies.

\section{Joint Venture}

The joint venture is one of the strategic alliance types which is characterised by shared ownership, shared governance and shared performance. This strategy is known as equity alliances, which are likely to attract more profitable target firms (Kim and Palia 2014). It seems to be more practical for foreign companies to choose acquisition or green entry mode that creates global operations, which need to fulfil various requirements, from benefits for local employees, new distribution channels to regulatory approval for the operations (Lebedev et al. 2015). The joint venture allows the companies to have a smooth local launch by creating an entirely new local entity. However, joint ventures with local companies bring the disadvantage of diminished autonomy. Critical management issues sometimes require a two-thirds vote or an agreement of a supermajority without ignoring the influence of a minority partner on the management (Motohashi 2015).

This strategy is, namely, equity alliance, which focuses on the wish to control the partner driving firms to enact self-serving monitoring decisions (Musarra et al. 2016). Ownership concentration has a positive association with firm performance (He and Ho 2009). Equitable value distribution does improve not only the relational capital of the network and a positive form of governance but also prompt imperfect performance that springs from multilateral feedback (Kano 2017). The wellfunctioning relationships between local stakeholders create a structure for network building, which might determine brand acceptance by the customers and stakeholders (Tarnovskaya and Biedenbach 2016).

\section{Licence Agreement}

A licence agreement does not bring a new business entity but is preferably a way to launch a new business in partnership with a local company on a contractual basis. The local firms pay a certain percentage of revenue to the multinational company as the licence fee. The multinational companies do not only provide products, which 
focus on functionality, but also provide services to the customers (Motohashi 2015). The multinational companies do not merely sell traditional products but consider selling the limited-term licence. The companies make a purchasing contract with the local distributors for goods or services at the particular time to cut inventory cost and loss associated with the uncertainty of demand (Wang et al. 2015). From the customers' point of view, purchasing contract is essential to enhance the integration of strategic services, which brings a tendency to create a strategic alliance with the suppliers.

The firms in the type of non-equity alliance bring about their explicit or implicit arrangements with partners at their interaction process to meet alliance-specific goals (Gudergan et al. 2016). This strategy requires the in-depth and long-term development of service offerings. The purchasing contract becomes the best interest of both players because the manufacturer contract has more responsibilities in material procurement (Hwang and Gaur 2009). The type of alliance is expected to accelerate development programme based on risk and revenue-sharing partnerships. The contractual agreement generates a sense of accountability for expanding effort or accomplishing their aims. This type of collaboration is characterised by the social interaction with trust to support the operation. Partnerships with revenue-sharing agreements face perceiving losses because of the challenge associated with satisfying their income goal. Firms should increase contractual safeguards to deal with opportunistic partners (Lui and Ngo 2004).

\section{Subcontracting and Outsourcing}

Firms may choose to outsource some aspects of product development to another company. They may not have much to gain technically from companies in targeted countries, but local sales necessitate the creation of customer relationships and retail and distribution channels, which can be difficult without support from local partners (Young et al. 2014). Partnering with companies with already existing local channels enables the rapid launch of operations. Outsourcing R\&D service industry is developed in India, while many companies also outsource their product development in China, mainly electronic and IT sectors (Motohashi 2015).

In emerging countries, many local businesses have no legal form or operate informally. This system implies on noncontractual collaboration, which involves no agreement or affiliation between the manufacturer and local distributors. It thus allows the distributors to change their pattern of purchases without informing the supplier or manufacturer partner. The main reason for this strategy is that the multinational company avoids exploitation by the distrusting partners rather than by an untrustworthy agent (Herold 2010). The supplier at this type of collaboration lays emphasis on the trustworthy partnership (Sariola and Martinsuo 2016). This relationship requires the social mechanism, which involves efficacy to enhance the functioning of collaboration (Kano 2017). 


\subsection{Institutional Environment and Alliance Management Capability}

Alliance management capability refers to the capacity to create, extend or modify the firm's resources, which are augmented to include the resources of its alliance partners (Schilke 2014). Alliance capability is essential for inter-organisational relationships, which demonstrates partners' ability to play the role of a catalyst in generating the partnership value. For local firms, developing network ability is essential to go for a partnership with a multinational corporation (O'Toole and McGrath 2017).

The institutional dynamics shape the costs and benefits and therefore influence the choice of collaboration strategy (Hwang and Gaur 2009). Even when institutions are better developed, foreign corporations still use collaboration strategies as entry mode because they focus on product-related inefficiency in markets (Meyer et al. 2009). By examining the data of the top 500 Indian and Chinese firms, Singh and Gaur (2009) provide evidence that institutional context also determines the performance of strategic alliance (Singh and Gaur 2009). New local partners are required to be able to quickly generate advantageous network positions as the development of their ability (O'Toole and McGrath 2017).

Strategic alliance integration is growing momentum to improve the chances in the marketplace through complimentary group war strategy, which could help firms to enhance their competitive advantage (Peng 2003). To generate benefit from the collaboration strategies, it requires the ability to recognise and tolerate mistakes to encourage exploration of superior solutions and, thus, effectively engage in the learning process (Weinzimmer and Esken 2017). The business group-affiliated firms leverage collaborative strategy to achieve performance, especially in emerging economies, such as India (Popli et al. 2017).

The strategic alliance process involves various steps from partnership establishment, joint activities, formulation of a partnership strategic plan and implementation of tactic at both multinational companies and local partners (Clarke and Fuller 2010). Incentive alignment in IS networks requires the establishment of a communication platform connecting the producers with regulatory bodies, environmental expert and community advocates. Firms engaged in national and regional collaboration networks are more likely to have a stronger patenting propensity, while international collaboration networks have no significant impact on the performance of research and development (Bolivar-Ramoz 2017).

Firms can benefit from the ability to deal with these contradictions as paradoxes, which can be managed by making the deliberate choice in temporal and spatial contexts (Young et al. 2014). The greater formal institutional distance between the home country and the host country also leads the decision to make a choice in crossborder alliance decisions (Meyer et al. 2009). While mistakes are usually not desirable, having a forgiving environment that supports the notion of learning from previous mistakes may encourage the organisational learning process (Weinzimmer and Esken 2017). 


\subsection{Institutional Environment}

The institutional environment incorporates the political, social and legal ground rules that set up the basis for producing and distributing economic activities. A robust institutional environment refers to a condition in which a business gains support from an effective market mechanism (Meyer et al. 2009). On the other hand, the underdeveloped institution refers to a condition that undermines markets, such as corruption, lack of legal protection for property rights, poor commercial law enforcement, non-transparent judicial systems and inefficient market intermediaries (Wu and Chen 2014).

In emerging countries, companies must exercise caution because government regulation often caps the level of investment by foreign firms. Under institutional transition, the multinational companies face uncertainty about the strategic actions that will bring legitimacy in the changed context (Hwang and Gaur 2009). Under moderate level of institutional transition, multinational companies tend to take the strategic position to exploit the growth opportunities. Legitimacy is a central part of neo-institutionalism, which points out that organisations seek legitimacy to meet their expected performance that involves a regulative and administrative system (Meyer et al. 2009). Hence, the existence of flexible legal framework and business formalization incentive programs is essential for business partnership possibilities (Pratono and Sutanti 2016). However, as the intensity of institutional reform increases, the companies are less likely to take wait-and-see strategy by reducing the existing resources and capabilities (Singh et al. 2018).

Dynamic institutional environment shapes the organisational actions from innovation, partnership, and other commercial process. The institutional environment at a national level can facilitate the initiative to sustain the economic incentive and to gain trust in the collaboration. Many firms in emerging economies get involved in political activities to control the hostile institutional environment (Zhou 2017). The extent to which the institution environment avoids political intervention in business becomes an incentive for international alliance strategy (Henisz and Zelner 2001). The efforts to strengthen the institutional environment suffer from an institutional contradiction, which results from the institutional conflicts (Voronov and Yorks 2015). E-government is another initiative to enhance the institutional setting by promoting transparency (Rodríguez-Bolívar 2014). The institutional climate explains only some variance of foreign direct investment, performances and the decision-making process (Gomes et al. 2016).

\section{Method}

This study used a qualitative approach with a case study of the medical device industry to examine how the institutional environment affects the choice of the alliance strategy. The case study was undertaken over 5 years (2012-2017) through 
a series of observation and interviews. The case-study approach allows the researchers to go beyond initial mainstream conceptions of alliance strategy in global business and to identify the complexity of the context of the institutional environment (Rittenhofer 2015).

The early step of data collection focused on building the relationship and trust with research participants. The flexible interview allows in-depth analysis to focus of study on the views of the research participants (Wimpenny and Gass 2000) to understand the behaviours of the observed respondents in dealing with their challenging issue (Rogelberg 2004). The data collection involved observation and interview with open-ended questions. This approach encouraged research participants to share their experiences. The flexible approach allowed participants to elaborate the phenomena from their point of view, while the researcher tried to carefully adapt to the context with non-judgemental questions (Zhang and Guttormsen 2016).

The data collection also concerned on the relevant fragments to gain support from the possible theoretical directions to understand what is happening in the setting, in the people's lives and in lines of the recorded data. To gain balanced information, the researchers concerned with triangulation from various observation and interview with a cross-validation method (Miles and Gilbert 2005). This research involved the semi-structured interview with the managers from multiple backgrounds, i.e. multinational enterprises, local firms and customers. The data collection was carried out from 2013 to 2017 . The companies included in this study focused on medical products, i.e. surgical refractors, hypodermic needles, lung ventilators, bone fixation, suction equipment, heart valves and hospital furniture.

The interviews were recorded with permission and transcribed. We began by asking about alliance strategy between the multinational enterprise and local companies. As the open-ended questions created the condition that enables the respondents to answer spontaneously, the managers are encouraged to tell the stories about their experiences. Once the atmosphere had been created in the interview, we focused specifically on the ways to attract and motivate global partnership, seeking to understand how the participants experience or make sense of the issue. The questions were deliberately open and included the following: How do you find the alliance strategy? Do you think that the selected strategy is the most relevant? Does it need changing? Why?

Following the procedures recommended in previous interpretive studies, we analysed the data in three different phases:

1. We read each transcript to understand the general grasp of the experience.

2. We dialogued with the data by assessing the extent to which there was the discrepancy between our preliminary description of alliance strategy and the way alliance strategy was experienced at the observed corporations. The dialogue occurred on the areas where the differences appeared (e.g. wholly owned subsidiary, joint venture, licence agreement and subcontracting). 
Table 1 Profile of respondents

\begin{tabular}{l|l|l}
\hline Respondents & Position & The countries/cities of origin \\
\hline R1 & Managers of the multinational corporations & $\begin{array}{l}\text { Europe, USA, Japan, Korea } \\
\text { China }\end{array}$ \\
\hline R2 & Managers of the large distributors & $\begin{array}{l}\text { Jakarta, Surabaya } \\
\text { Denpasar, Medan, Makasar }\end{array}$ \\
\hline R3 & Managers of the small distributors & $\begin{array}{l}\text { Jakarta, Surabaya } \\
\text { Denpasar, Medan, Makasar }\end{array}$ \\
\hline R4 & Managers of the public hospitals & $\begin{array}{l}\text { Jakarta, Surabaya } \\
\text { Denpasar, Medan, Makasar }\end{array}$ \\
\hline R5 & Managers of the corporate hospitals & Jakarta \\
\hline R6 & Managers of the small private hospitals & $\begin{array}{l}\text { Jakarta, Surabaya } \\
\text { Denpasar, Medan, Makasar }\end{array}$ \\
\hline Auna
\end{tabular}

Authors' own table

3. We formulated our final interpretation of the criteria of alliance strategies and then compared them with the previous studies. This approach allowed us to assess the extent to which our interpretation provided the new alternative view on theoretical insights (Table 1).

\subsection{The Institutional Context}

This study identifies two types of institutional environment, which determines the collaboration strategies between foreign companies and local firms in the medical device industry. The first type of institutional environment plays a regulatory role to protect the population from medical errors and enhance patient safety, including the development, evaluation and supervision of the health technology and practices. Second, the government has a responsibility to purchase medical devices to provide health services for the population. The policy implies on administration role, which encouraged the shifts in the strategic alliance.

First, in Indonesia, it is compulsory for the foreign manufactures of medical devices exporting their products to Indonesia to comply with the applicable regulations. These regulations require the producers or suppliers to register their products with the Indonesian Ministry of Health to be listed in the Indonesia Medical Device Registration. It could be the Indonesian subsidiary of the product owner (manufacturer) or a local company that is authorised by the multinational companies to submit the product registration application.

The Government of Indonesia encourages multinational companies to invest in the production of healthcare medical device in Indonesia, which may form an equity-based collaboration or a merger and acquisition strategy. (Previously, the multinational companies are not interested to set their representative offices in Indonesia. They prefer to establish their offices in Singapore.) In 2016, the Presidential Regulation No. 44 of 2016 revised the regulation and allowed the multinational 
manufacturers to establish their businesses with $100 \%$ equity ownership. Foreign companies, which do not concern on the production process, are allowed to own $67 \%$ of total equity (Indonesia Investment Coordination Board 2016).

The Ministry of Trade Regulation No. 11/M-DAG/PER/3/2006 states that it is compulsory for foreign companies in wholesaling or distribution to have a partnership with a local trading company to do the trading activities. According to the Law $20 / 2008$, the international firm is classified as a large company enterprise. This policy allows the foreign firms to manage equity above IDR10 billion (approximately USD 1 million) or annual income above IDR 50 billion (approximately USD 5 million). The Ministry of Trade Regulation No. 22/M-DAG/PER/3/2016 states that the local partner should take a role as an agent, a sole agent or a distributor.

The Indonesian Ministry of Health imposes the regulation of 190/MENKES/ PER/VIII/2010, which defines that medical devices include the instruments, apparatuses, machines and/or implants. The definition excludes drugs, which are used to prevent, diagnose, cure or relieve diseases. To sell or distribute their products in Indonesia, the firms are required to meet the quality standard for medical devices (ISO 13485 for QMS) and have licence for good distribution practice and registration licence (ASEAN CDST). It was the National Agency of Drug and Food Control Division that has authority to regulate the medical devices for safety and quality.

Second, the Indonesia public hospitals play a pivotal role to support the government to achieve the ambitious plan of the largest universal health coverage. The public hospitals heavily relied on the local budget, which can be used to provide the infrastructure and equipment at public health facilities, including the emergency care devices, immunisation devices, health laboratory devices, health promotion devices and mobile health centres (World Bank Group 2016). How does this affect the foreign companies?

The National Security System has already driven sales of medical devices, such as MRI machines and PET-CT scanners, of which most were imported. The National Security System was expected to achieve the targeted performance of universal health coverage. The technology of healthcare and medical devices is a driving force in enabling healthcare provision, which in turn creates the demand for more medical devices. This policy involves various stakeholders, including multiple levels of government and suppliers of medical devices (Mboi 2015) (Table 2).

In 2003, the Government of Indonesia began to reform the procurement system of public goods following the Presidential Decree No. 80/2003 and succeeded by Presidential Regulation (Perpres) No. 54/2010 in 2010. In 2007, the National Public Procurement Agency (LKPP) and Procurement Service Units (ULP) were established to develop the electronic procurement systems. The system has become the valuable innovation for improving governance, which needs appropriate implementation through careful consideration of the context (Choi et al. 2016). However, local firms where small-scale businesses are in the majority may face difficulty to face the business technological turbulence (Pratono et al. 2018). 
Table 2 Identified alliance strategies and institutional environment

\begin{tabular}{l|l}
\hline Types of alliance strategy & $\begin{array}{l}\text { Alliance capability to deal with the institutiona } \\
\text { environment }\end{array}$
\end{tabular}

Partnership with the reliable local distributors
by the licence agreement environment

As there is a prohibition to carry out direct sales, the long-term agreement allows the multinational companies to focus on marketing strategy and aftersales services and invite a single distributor with a strong capability to manage the whole national market

Partnership with the small local distributors by the contractual collaboration

As the foreign companies are prohibited from the direct selling of imported products to the state-owned hospitals, the multinational corporations collaborate with the local firms to achieve their targeted performance by selecting the specific target market

The multinational corporations require managing the capability to manage the local distributors. Each local distributor is expected to focus on one small private hospital with a more straightforward procurement than public hospitals

Partnership with authorised distributors by managing the business from abroad

The agreement makes the multinational companies rely on their local distributors to achieve their targeted performance by providing autonomy to set the price before a bid for the public hospitals with e-procurement system

Establishing the equity alliance venture (joint venture) to address the local content

Responding to the dynamic environment from protection to open policy, the multinational requirement companies began to choose acquisition or the green entry mode, which allows them to manage global operations by focusing on the lowtechnology product, such as hospital furniture and disposal products.

Subcontracting the minor business activities for the local partners

The regulation imposes the outsourced services should be noncore activities, such as support services, security services, transportation, warehouse and delivery system

Authors' own table

\section{Findings}

This study identified types of market penetration and strategic alliance in the medical device industry in Indonesia: wholly subsidiary with the licence agreement, purchasing contract, noncontractual collaboration, non-equity contractual collaboration and equity alliance. 


\section{Partnership with the Reliable Local Distributors by Establishing Wholly Subsidiary with the Licence Agreement}

The MNC goes into collaboration by providing a long-term licence to the local distribution firms for selling their products in the whole country. The activities of importing medical devices require full compliance with all applicable safety standards which becomes the main reason for this strategy. The strategy allows the distributors to focus on sales, while marketing strategy and aftersales service become the responsibility of multinational companies. The multinational companies manage the networks with valuable customers by providing the aftersales services and the customer preferences. Hence, the multinational companies select the local partners based on the product lines, the market coverage area or the market segmentation.

My company establishes the representative office in Jakarta with few numbers of staffs, who will not be able to cover the country with 240 million populations and more than 13,000 islands. So, we go to partnership with local companies to reach our markets. R1

I work for a local company, which focus the market in East Indonesia. We get the license agreement to sell the products from a foreign company to sell the products in the specific market area, i.e. East Java Province, Bali, and Sulawesi Island. In some cases, the local buyers have a strong connection with their headquarter in Jakarta. As the decision maker took place in the capital city, our company finds a problem to execute that the transaction. R3

We are a corporate hospital, which manages more than 25 hospitals in this country. The decision making goes to the headquarter, which allows us to buy directly from the multinational corporations. R5

For local distributors with product line agreement, every product line has different targeted performances. At this type of agreement, the multinational companies need to develop a marketing strategy with a various level of product development. The local distributors are expected to focus on one or two products with direct markets to the whole country.

The agreement with market coverage area encourages the local distributors to enhance their networks with other local partners. It is essential for the multinational companies to identify the capability of the local distributors. The local distributor typically was selected based on the previous experience with another brand. They have already managed the market area with local partners or third parties.

Companies with the agreement on market segmentation divide the local distributors into two types of customers: the public hospitals and the private hospitals. The private hospitals fall into corporate hospitals, which typically manage the activities in Jakarta. For the private hospitals, the multinational companies may take over the direct market, while the small local distributors are encouraged to focus on small corporate hospitals.

There are also some exclusive agency agreements. The local firms need to have the capability to handle the whole market in Indonesia. The selected distributor typically has the licence for e-catalogue of the medical devices that the companies 
produce. For the licence of maintenance service, the principal provides regular training to the local partners to make sure the capability and resource are available.

\section{Partnership with the Small Local Distributors by Establishing the Wholly Owned Subsidiary with Contractual Collaboration}

The multinational company with this type of strategy manages a representative office to carry out import, sales, distribution and maintenance services. For selling activities, the subsidiaries focus on the selected main customers, such as teaching and chain hospitals. The teaching hospitals are expected to introduce the brand to their networks or provide a valuable reference to promote brand credibility. Hence, the company goes for a partnership with the local distribution firms to achieve the targeted market share by establishing annual contractual collaboration. Typically, there were few types of products with a strong brand and highly sophisticated technology.

I work for a multinational company, which just established a representative office in Jakarta a few years ago with two branch offices in Surabaya and Medan. The regulation encourages the government-owned hospital to buy the equipment from local companies. Hence, we sell our products to public hospitals through a local channel. However, we can sell directly to the local private hospital. R1

Our hospital prefers to buy the devices directly from the company, which produces the products. The service is much better than other companies, which provide the license to the local distributors. The service includes product training, complaint handling, education program, and maintenance services. R4

The representatives also invite local firms to sell the products without any contractual agreement. The multinational companies develop a specific strategy for each partner to approach the targeted hospital or customer. One distributor may focus on one or two hospitals. This approach is suitable for new entry products. This strategy is also more relevant to low brand credibility. They need to identify the capability of their local partners, which have a unique capability to deal with the multiple levels of the institutional environment. The small local distributors focus on the small private hospitals with a more straightforward procurement than public hospitals. When the multinational companies gain benefit from popular brands, they become overwhelmed to respond to the proposal for collaboration with the local firms.

\section{Managing the Business from Abroad by Exporting the Products and Providing the Authorised Distributor Agreement to the Most Significant Local Partners}

Under the authorised distributor agreement, there was no representative office of multinational companies in Indonesia. The local companies go for a partnership with a large local distributor to deal with the local market, including the state-owned hospital with e-procurement system. The agreement makes the multinational companies rely on their local distributors to sell their products with autonomy to set the price before a bid for the public hospitals with e-procurement system. 
First, it will be an advantage if the local distributors have secure access to the primary customers, especially the public hospitals. The multinational companies entirely rely on the local distributor to deal with the institutional environment and market competition. The multinational companies focus on maintaining the networks with the local distributors. As consequences, the companies provide the delivery of the product knowledge to the distributor. The product managers from the multinational enterprises offer various training activities to the local distributors, and they do not have direct contact with the customers.

Second, it was too much of a risk for the multinational companies to invest in the targeted marketplace, especially when the amount of demand does not sufficiently meet the expected supply. This strategy is likely to be relevant when the government imposes policy to control the foreign investment, and the local distributors remain to dominate the local market, which happened before 2006. As mentioned above, the Indonesian Ministry of Trade Regulation No. 11/M-DAG/PER/3/2006 encourages all foreign companies to go for a partnership with a local trading firm in the trading activities.

My company comes from Europe with a regional office in Singapore. We do not establish a representative office in Indonesia but prefer to collaborate with a local company with a purchasing contract to sell our products as well as to provide after-sales services. R1

I work for a multinational company, which provides a license agreement to one big local company that manages to import and to sell our products with the high safety standard. The company has strong local networks, including after-sales services at the public hospital. R1

The medical equipment is one of the emerging businesses for my company, which $100 \%$ belongs to a local resident. The company has a strong capability to manage the whole national market with a headquarter in Jakarta and five branch offices in five big cities in Indonesia. Having a headquarter in Jakarta provides an advantage to get access to the decision maker. R2

At the early step of the market reform, the government still becomes the main buyer by establishing a local public hospital. The hospital needs devices which the multinational firms from developed countries produce. Along with a secure network of customers, the distributors get authority over the selling activities. Distributors also have a responsibility to get a product licence for e-catalogue, which is essential for a procurement process at the public hospitals. However, when the multinational manufactures introduce a new product development, the multinational companies become a concern with strategy in marketing a new brand. This strategy requires the multinational companies with a strong capability to manage the networks with the customer, i.e. the hospital management and the medical staff as users. This approach raises a potential conflict when the multinational companies approach the customers.

\section{Addressing the Local Content Requirement for Low-Technological Products by Establishing the Equity Alliance Venture}

The strategy was preferable when the principal companies allocated their resource to support the local partners, which had an intention to develop a medical device 
assembly plan. This type of alliance demonstrates how the multinational firms expand the production process in the country with minimum resources to keep the cost at a minimum level and to deal with minimum risk.

The observed multinational firms allocated scarce capital to subsidiary firms with low-technological products, e.g. the hospital furniture. This study did not find any multinational firms that invested a sophisticated product, such as critical care products.

They produce the high local-content production. This strategy allows the local firms to improve their role from distribution to marketing. This approach, in turn, relies on the local company to deal with various regulations, which include e-catalogue licence. After being established, the new alliance companies began to establish the license unit to manage the license in salesforce.

Our organisation is a local company, which does not only have a license to sell imported hospital equipment products but also produce disposable products. The production division is a joint venture company, which establish manufacture that produces hospital furniture. R2

Our hospital buys medical supplies from local manufacture, which is undertaken jointly by local and foreign companies. We never buy medical equipment from local companies. R6

\section{Focusing the Main Business Activities by Outsourcing or Subcontracting the Minor Business Activities for the Local Partners}

According to the Regulation No. 19/2012 that was issued by the Ministry of Manpower, there are two types of outsourcing: services and labour supply. These types of work are preferably for outsourcing system with contract service basis that has tasks that need to be performed separately from the core activity of the company. As the company at the medical device industry focuses on trading activities, the subcontracting activities include the installation of workplace and infrastructure for pendant and radiology products.

As the partnership does not incorporate informal sectors, even for the small amount of project, the local partners are encouraged to register their organisations prior to subcontracting a small project tender. Many small local partners are informal sectors and have no licence to run a company. They take a risk by borrowing the legal name from another firm to get a contract for doing business activities with the healthcare companies. This strategy typically occurs with new entrance local firms, which consider legal form as still costly (Table 3).

\section{Discussion}

Traditionally, there are four types of alliance strategy: wholly owned subsidiary, licence agreement, joint venture and outsourcing. The multinational companies not only choose one type of alliance strategy but also combine some of them. For companies that prefer not to set up a subsidiary at the targeted country, they need 
Table 3 Principle-distributor alliance strategies

\begin{tabular}{|c|c|c|}
\hline Types of alliances & Criteria for alliance strategy & $\begin{array}{l}\text { Included criteria from the case } \\
\text { study }\end{array}$ \\
\hline $\begin{array}{l}\text { Partnership with the reliable } \\
\text { local distributors by the } \\
\text { licence agreement }\end{array}$ & $\begin{array}{l}\text { This contractual agreement } \\
\text { emphasises the role of multi- } \\
\text { national companies in control- } \\
\text { ling the local entities by } \\
\text { providing universal } \\
\text { standardised products }\end{array}$ & $\begin{array}{l}\text { The multinational companies } \\
\text { select the local partners based } \\
\text { on their capability to manage } \\
\text { the product lines, the market } \\
\text { coverage area or the market } \\
\text { segmentation }\end{array}$ \\
\hline $\begin{array}{l}\text { Partnership with the small } \\
\text { local distributors by the con- } \\
\text { tractual collaboration }\end{array}$ & $\begin{array}{l}\text { The agreement allows the local } \\
\text { firms to sell the products for } \\
\text { the whole customers without } \\
\text { aftersales services }\end{array}$ & $\begin{array}{l}\text { There is no fee for mainte- } \\
\text { nance and procurement } \\
\text { licences, but all distributors } \\
\text { are required to achieve } \\
\text { targeted sales performance }\end{array}$ \\
\hline $\begin{array}{l}\text { Partnership with authorised } \\
\text { distributors by managing the } \\
\text { business from abroad }\end{array}$ & $\begin{array}{l}\text { The agreement makes the } \\
\text { multinational companies rely } \\
\text { on their local distributors who } \\
\text { have authority to manage the } \\
\text { whole market in the country }\end{array}$ & $\begin{array}{l}\text { The multinational companies } \\
\text { focus on maintaining the net- } \\
\text { works with the local distribu- } \\
\text { tors by delivering the product } \\
\text { knowledge to the distributor }\end{array}$ \\
\hline $\begin{array}{l}\text { Establishing the equity alli- } \\
\text { ance venture (joint venture) to } \\
\text { address the local content } \\
\text { requirement }\end{array}$ & $\begin{array}{l}\text { The multinational companies } \\
\text { allocated intangible assets to } \\
\text { the subsidiary manufacture to } \\
\text { produce the low-technological } \\
\text { products, e.g. the hospital } \\
\text { furniture }\end{array}$ & $\begin{array}{l}\text { The multinational companies } \\
\text { manage the global operations } \\
\text { by establishing the joint ven- } \\
\text { ture to fulfil various require- } \\
\text { ments from benefits for local } \\
\text { employees, new distribution } \\
\text { channels to regulatory } \\
\text { approval for the business } \\
\text { activities }\end{array}$ \\
\hline $\begin{array}{l}\text { Subcontracting the minor } \\
\text { business activities for the local } \\
\text { partners }\end{array}$ & $\begin{array}{l}\text { Joint operating agreements } \\
\text { allow the multinational com- } \\
\text { pany to focus on the core } \\
\text { business. The construction } \\
\text { risk, such as delays in con- } \\
\text { struction, should be borne by } \\
\text { the local partners }\end{array}$ & $\begin{array}{l}\text { The subcontracting activities } \\
\text { include the installation of the } \\
\text { work and infrastructure for } \\
\text { pendant and radiology prod- } \\
\text { ucts } \\
\text { The local partners are encour- } \\
\text { aged to register their organi- } \\
\text { sations before the } \\
\text { subcontracting project tender }\end{array}$ \\
\hline
\end{tabular}

Authors' own table

to go for a partnership with local companies by giving licence for two reasons. Either (1) the local firm is too strong, and it requires a considerable effort to take over the market, or (2) the government policy controls the power of foreign companies.

Secondly, this study identifies that the collaboration between the multinational enterprises and the local distributors was extended by the licence agreement, contractual agreement and authorised distributor agreement. The observed companies with a representative office in this country have two agreements with local firms, licence and contractual agreement. The licence agreement allows the multinational enterprises to manage the marketing strategy and aftersales service by focusing their sales activities on the teaching hospitals as the strategic customers. Multinational 
enterprises with the contractual agreement encourage their local partners to allocate more resources by allowing them to manage the sales activities.

This study also identifies that there are two types of institutional environment, which determines the collaboration strategies between foreign companies and local firms in medical devices: firstly, the government intervention to protect the people to enhance patient safety, including development, evaluation and monitoring of the health technology and practices, and, secondly, the government intervention in the market by purchasing the medical devices to provide the health services. Lastly, the government plays a pivotal role in controlling the medical equipment markets. This strategy includes the restriction for the multinational companies to carry out direct selling to the state-owned hospitals, which encourages the companies to collaborate with the local distributors.

Strengthening the institutional environment encourages collaboration strategy at the expense of joint ventures. The intention of the government to fulfil the universal health coverage is thought to play an essential part in the regulation of medical devices, especially the administration system, which encourage the shifts in the strategic alliance. This approach becomes pertinent to the observed case in which the government plays a pivotal role as a buyer and a policymaker for medical devices.

There is a dynamic policy regulation of institutional environment, involving the regulation of foreign direct investment, nationally standardised system, fair competition, financial control, medical product safety and decentralisation of the public healthcare system. This approach becomes central for the choice of collaboration strategy at the medical device market in Indonesia. Another administration improvement, such as the electronic procurement system, has led to the detailed contractual agreement and implies for the strategic alliance, which concerns on setting the most competitive price.

Turning the collaboration capability, multinational companies are required to develop their capacity to manage the collaboration with the local firms, which becomes the main reasons for the choice of strategies. Some organisations may expand their capabilities to maintain their alliance over the years and regard them as core competencies. They create a managerial division to institutionalise the process from identifying the potential partners and negotiation to take issues that arise after the agreement.

The equity relationship allows the multinational companies and acquires the local partners at the right time to pre-empt rival. However, the high degree of uncertainty around the institutional environment becomes the main reason for the company to use alliance as stepping stones to acquisitions. The restriction for foreign companies to carry out direct selling has brought about significant changes in selecting the types of the collaboration strategy. They have an alternative strategy whether they choose a robust national-level distributor or several local small distributors.

The foreign companies face various types of the target market, which determine their strategies. For the state-owned hospital, the multinational companies prefer the robust national-level distributors with a secure network to the central government and local government. Secondly, the target market could be the corporate hospitals 
with a centralised decision-making process at the capital city. This strategy also requires a reliable partner with the capability to provide services to the whole country. Lastly, the local private hospitals in other small towns also offer opportunities. The foreign companies need efforts to access this type of hospitals in the archipelagic country with more than 13,000 islands.

\subsection{Policy Implication}

Both the multinational companies and the local distributors need to define the role of each player to support the dynamic capability of B2B collaboration strategies. Lean management system makes a clear strategy and presents it for everyone in the organisation to ensure leaders' efforts help the frontline work necessary to meet the effective strategy. The governments across emerging economies countries fight bureaucracy by explicitly restructuring their e-governance systems to provide the best healthcare services.

Rapid change in government policy, the capability of the local partners and the strategy of hospital costumers characterise dynamic environments. To adapt, the collaboration between the multinational companies and the local distributors should not only identify the fast-moving condition, such as new products, new policy and changing competition, but also should know where to look for signs of accelerating change, which may come from information technology.

\subsection{Research Limitation and Future Studies}

The first limitation of this study is that the case study examined the collaboration strategy B2B with a specific issue of medical devices in Indonesia. Further studies in other fields are needed to confirm the type of changing strategies and increase their generalisability. Second, this study was conducted from 2012 to 2017, when the most popular strategy was non-equity contractual. The institutional environment changed in 2016 by allowing the multinational manufacturers to establish their businesses in Indonesia with $100 \%$ equity ownership. Future studies are encouraged to identify the impact of this policy. However, the number of observed multinational enterprises running a business in Indonesia was limited. To gain a profound empirical result, future studies are encouraged to observe the global context, which involves a more significant number of multinational corporations. 


\section{Conclusion}

This study reveals the several types of strategies where the multinational corporations penetrate the Indonesian medical device market by carrying out the contractual purchases, noncontractual collaboration, non-equity collaboration and equity alliance.

The result extends the discussion on how the institutional environment determines strategic alliance choices in the global trade literature (Gomes et al. 2016). This article also extends the institution-based research by focusing on collaboration strategy between the multinational enterprises and local distribution firms.

By adapting to the institutional environment context, the alliance strategy between corporate and local partners has developed. These results extend the works of the prior studies (Motohashi 2015; Gomes et al. 2016; Singh et al. 2018), which examines the types of alliance strategy and the role of the institutional environment on the choice of alliances and consolidation strategies.

Acknowledgement The authors thank Dr Tina Miethank from King's College London and Dr Teoh Chai Wen from Sunway University, Malaysia, who provide the valuable review. We also extend our sincere gratitude to Prof Nezameddin Faghih from the UNESCO Chair in Entrepreneurship for inviting us to get involved at on this project.

\section{References}

Arnold, D. (2000, November-December). Seven rules of international distribution. Harvard Business Review, 8(6), 131-137.

Bolivar-Ramoz, M. T. (2017). The relation between R\&D spending and patents: The moderating effect of collaboration networks. Journal of Engineering and Technology Management, 46, 26-38.

Choi, H., Park, M. J., Rho, J. J., \& Zo, H. (2016). Rethinking the assessment of e-government implementation in developing countries from the perspective of the design-reality gap: Applications in the Indonesian e-procurement system. Telecommunications Policy, 40, 644-660.

Clarke, A., \& Fuller, M. (2010). Collaborative strategic management: Strategy formulation and implementation by multi-organizational cross-sector social partnerships. Journal of Business Ethics, 94(1), 85-101.

Contractor, F., Yang, Y., \& Gaur, A. S. (2016). Firm-specific intangible assets and subsidiary profitability: The moderating role of distance, ownership strategy and subsidiary experience. Journal of World Business, 51, 950-964.

Frost \& Sullivan. (2016). Indonesia healthcare outlook: Value position and market entry guides for Indian investors. New York: Frost \& Sullivan.

Gaur, A. S., \& Lu, J. W. (2007). Ownership strategies and survival of foreign subsidiaries: Impacts of institutional distance and experience. Journal of Management, 33(1), 84-110.

Gomes, E., Barnes, B. R., \& Mahmood, T. (2016). A 22 year review of strategic alliance research in the leading management journals. International Business Review, 25(1), 15-27.

Gudergan, S. P., Devinney, T. M., \& Ellis, R. S. (2016). Cooperation and compliance in non-equity alliance. Journal of Business Research, 69(5), 1759-1764.

He, L., \& Ho, S.-J. K. (2009). The Anglo-Saxon corporate governance model in Asia. Journal of Global Business Advancement, 2(1/2), 173-190. 
Henisz, W., \& Zelner, B. A. (2001). The institutional environment for telecommunication investment. Journal of Economics and Management Strategy, 10(1), 123-147.

Herold, F. (2010). Contractual incompleteness as a signal of trust. Games and Economic Behavior, 68(1), 180-191.

Hwang, P., \& Gaur, A. S. (2009). Organizational efficiency, firm capabilities, and economic organization of MNEs. The Multinational Business Review, 17(3), 143-162.

Indonesia Investment Coordination Board. (2016). Indonesian negative list revision. Negative List Seminar with JICA (pp. 1-6). Jakarta: Indonesia Investment Coordination Board.

Kano, L. (2017). Global value chain governance: A relational perspective. Journal of International Business Studies, 48(6), 1-22.

Kim, T.-N., \& Palia, D. (2014). Private equity alliances in mergers. Journal of Empirical Finance, $27,10-20$.

Lebedev, S., Peng, M. W., Xie, E., \& Stevens, C. E. (2015). Merger and acquisitions in and out of emerging economies. Journal of World Business, 50, 651-662.

Lui, S. S., \& Ngo, H.-Y. (2004). The role of trust and contractual safeguards on cooperation in non-equity alliances. Journal of Management, 30(4), 471-485.

Mboi, N. (2015). Indonesia: On the way to universal health care. Health Systems \& Reform, 1(2), 91-97.

Meyer, K. E., Estrin, S., Bhaumik, S. K., \& Peng, M. W. (2009). Institutions, resources, and entry strategies in emerging economies. Institutional, Resources, and Entry Strategies in Emerging Economies, 30(1), 61-80.

Miles, J., \& Gilbert, P. (2005). A handbook of research method for clinical and health psychology. Oxford: Oxford University Press.

Motohashi, K. (2015). Global business strategy: Multinational corporations venturing into emerging markets. Tokyo: Springer.

Musarra, G., Robson, M. J., \& Katsikeas, C. S. (2016). The influence of desire for control on monitoring decisions and performance outcomes in strategic alliances. Industrial Marketing Management, 55, 10-21.

O'Toole, T., \& McGrath, H. (2017). Strategic patterns in the development of network capability in new ventures. Industrial Marketing Management, 70, 128-140.

Peng, M. W. (2003). Institutional transition and strategic choices. Academy of Management Review, 28(2), 275-296.

Popli, M., Ladkani, R. M., \& Gaur, A. S. (2017). Business group affiliation and post-acquisition performance: An extended resource-based view. Journal of Business Research, 81, 21-30.

Pratono, A. H. (2018). From social network to firm performance: The mediating effect of trust, selling capability and pricing capability. Management Research Review, 41(6), 680-700.

Pratono, A. H., Ratih, R. S., \& Arshad, D. (2018). Does entrepreneurial orientation autonomy foster SME growth under technological turbulence? The empirical evidence from Indonesia. Journal of Technology in Behavioral Science, 3(3), 170-178.

Pratono, A. H., \& Sutanti, A. (2016). The ecosystem of social enterprise: Social culture, legal framework, and policy review in Indonesia. Pacific Science Review B: Humanities and Social Sciences, 2(3), 106-112.

Rittenhofer, I. (2015). The reflexive case study method: A practice approach to SME globalization. International Journal of Entrepreneurial Behavior \& Research, 21(3), 410-428.

Rodríguez-Bolívar, M. P. (2014). Measuring E-government efficiency. New York: Sage.

Rogelberg, S. (2004). Handbook of research methods in industrial and organizational psychology. New York: Blackwell Publishing.

Rossignoli, C. (2015). Theories explaining inter-organizational relationships in term of coordination and control needs. In C. Rossignoli \& F. Ricciardi (Eds.), Inter-organizational relationships. Cham: Springer.

Sariola, R., \& Martinsuo, M. (2016). Enhancing the supplier's non-contractual project relationships with designers. International Journal of Project Management, 34(6), 923-936. 
Schilke, O. (2014). On the contingent value of dynamic capabilities for competitive advantage: The nonlinear moderating effect of environmental dynamism. Strategic Management Journal, 35, 179-203.

Singh, D. A., \& Gaur, A. S. (2009). Business group affiliation, firm governance, and firm performance: Evidence from China and India. Corporate Governance: An International Review, $17(4), 411-425$.

Singh, D., Pattnaik, C., Gaur, A. S., \& Ketencioglu, E. (2018). Corporate expansion during pro-market reforms in emerging markets: The contingent value of group affiliation and diversification. Journal of Business Research, 82, 220-229.

Tarnovskaya, V., \& Biedenbach, G. (2016). Multiple stakeholders and B2B branding in emerging markets. Qualitative Market Research, 19(3), 287-309.

Voronov, M., \& Yorks, L. (2015). "Did you notice that?" Theorizing differences in the capacity to apprehend institutional contradictions. Academy of Management Review, 40(4), 563-586.

Wang, X., Li, F., Liang, L., Huang, Z., \& Ashley, A. (2015). Pre-purchasing with option contract and coordination in relief supply chain. International Journal Production Economics, 167(9), $170-176$.

Weinzimmer, 1. G., \& Esken, C. A. (2017). Learning from mistakes: How mistake tolerance positively affects organizational learning and performance. The Journal of Applied Behavioral Science, 53(3), 322-348.

Wimpenny, P., \& Gass, J. (2000). Interviewing in phenomenology and grounded theory: Is there a difference? Journal of Advanced Nursing, 31(6), 1485-1492.

World Bank Group. (2016). Indonesia health financing system assessment: Spend more, right and better. Washington, DC: World Bank.

Wu, J., \& Chen, X. (2014). Home country institutional environments and foreign expansion of emerging market firms. International Business Review, 23(5), 862-872.

Xie, E., Reddy, K. S., \& Liang, J. (2017). Country-specific determinants of cross-border mergers and acquisitions: A comprehensive review and future research directions. Journal of World Business, 52(2), 127-183.

Young, M. N., Tsai, T., Wang, X., Liu, S., \& Ahlstrom, D. (2014). Strategy in emerging economies and the theory of the firm. Asia Pacific Journal Management, 31, 331-354.

Zhang, L. E., \& Guttormsen, D. S. (2016). "Multiculturality" as a key methodological challenge during in-depth interviewing in international business research. Cross Cultural \& Strategic Management, 23(2), 232-256.

Zhou, W. (2017). Institutional environment, public-private hybrid forms, and entrepreneurial reinvestment in a transition economy. Journal of Business Venturing, 32(2), 197-214. 